\title{
Discussion on English Grammar Teaching from the Perspective of Educational Psychology
}

\author{
Huan Deng \\ English Department, Wuhan College of Media and Communications, Hubei, China \\ helyndeng@qq.com
}

\begin{abstract}
Keywords: grammar teaching; educational psychology; cognitive factors
Abstract. The purpose of college English teaching is to help students transfer their English knowledge into communicative tool in language practice. Grammar is a prerequisite to the mastery and application of language. The traditional English grammar teaching, which relies mainly on dull recitation while plentiful exercises tactics subsidiary, nowadays has become inadaptable to the social development. Closely combining with the practical teaching of grammar course in specialized English from the educational psychology, this paper attempts to analyze, from many aspects, the features of grammar teaching and the psychological characteristics for English majors in the process of learning in order to improve the learning efficiency of grammar and to enhance the grammar teaching into its best results. Meanwhile, this paper will provide some lessons for the grammar teaching in college English course.
\end{abstract}

\section{History and Current State of Grammar Teaching}

Teaching is both a science and an art. At present, our English grammar teaching has an urgent need for teachers to adopt new methods in addition to guiding students toward more efficient learning, and break away from the dull routines of traditional grammar classes. Grammar teaching can only become more effective with two-way communication between the teacher and the students.

The prevailing methods in traditional grammar teaching are the translation method and the listening and speaking method. The translation method emphasizes the use of "systematic explanation, deepening of understanding, and combination of teaching and practice". The listening and speaking method asks students to practice analogy on grammar features during listening and speaking exercises, “forming a reflexive mastery over grammar structures.”(Cui Xuemei, 2008) In the early years of China's opening up and reform, the more frequent opportunities for communication with foreigners had increased people's need for English learning, as well as lead to the rise of the grammar communication method. This approach emphasizes the communicative function of language, and deemphasizes grammar learning, requiring learners to obtain grammar knowledge during their actual exchanges. As a result, the importance of grammar in English teaching was reduced, and for a period, grammar classes even disappeared from the curriculums of English majors. This had the side effect of making it difficult for many English learners of the time to comprehend complex sentences, who tended to frequently make basic grammar mistakes in their writing.

Now we may ask, what is the current state of English grammar teaching? Are the prevailing approaches the traditional translation, listening and speaking, or the popular communication method? In the author's own teaching practice, grammar teaching in most cases involves a combination of the three methods, rather than a singular approach. Therefore, according to the experience, the author has summarized three issues that are worth our consideration and require improvements:

(1) Teaching objects: the objects of the grammar classes in professional English curriculums is English major students, who tend to possess some foundational abilities and grammar knowledge. However, we need to realize that on one hand, the student pool of English majors in independent colleges is deeply affected by factors including differences in socio-economic development between regions and between urban and rural populaces, as well as the frequently unbalanced academic performances of one student in difference subjects. Compared to English majors in traditional prestigious schools, the students' English abilities are more likely to be highly non-uniform, and they generally have neither a strong foundation nor good learning habits. On the other hand, in China's 
current English curriculum design, the teaching of basic grammar features is designed to be completed during the middle school phase. During the first and second years of college, English major students may only get some grammar practice during their general English classes. Hence for most students, grammar learning is characterized by a state of incomplete comprehension, while their lack of good learning methods and habits gives them more cause to be scared of grammar learning. For this reason, teachers must approach students from the perspective of cognitive psychology, and arrange their grammar lessons according to their psychological characters.

(2) Grammar courses: the currently common grammar textbooks are structured according to singular grammar topics, moving from lexicology to syntax to discourse. While appearing systematic, this structure does not give enough emphasis to the interconnectivity of knowledge. Due to the weaker foundations of English majors in independent colleges, teachers are also likely to emphasize the explanation and exercise of singular grammar topics in their teaching, more or less repeating the grammar teaching model of senior middle school. We must remember that as a language, the grammatical characteristics of English are interconnected. Learning of singular grammar features is absolutely necessary, but it is meaningless without comprehensive practice within context.

(3) Teachers: teachers face a tension between the goal of grammar teaching and the need to pass English tests. In recent years, various English tests have gradually replaced grammar problems with other types of problems. This reform has led to some students missing the goal of grammar learning, even causing some teachers confusion regarding how their grammar teaching should be organized, making their teaching reactions to tests, rather than proactive delivery of knowledge. The goal of English teaching is to improve the students' general abilities in English, including listening, speaking, reading, writing and translation. Grammar learning is the invisible bond that ties these five areas together. Thus it is the teachers' mission to ensure their visible teachings can be turned into the students' invisible application of grammar.

\section{Principles of Grammar Teaching}

In light of these issues, what principles should we teachers abide by in our grammar teaching? First, grammar teachers should follow a common principle: while we should emphasize the importance of grammar to the professional English curriculum, college grammar classes should never be the rote and simplistic repetition of middle school grammar knowledge, but rather aimed at developing students' awareness and abilities on grammar, teaching them to master the grammar layers, and build a structure of grammar. Second, in addition to the learning of singular grammar features and memorization, teachers should also emphasize the abilities to use grammar in communication, evolving "teaching a language" into "teaching a language as a way of communication". The teaching should expand the students' language knowledge, and allow them gradually gain control over grammar rules in practice and communication.

In the process of practicing these principles, there are several methods which could be concluded, such as induction, deduction and analogy. Teachers cannot define themselves in some limited teaching method while they should be well-versed in teaching grammars in order to make each period of grammar teaching with some systematical researches. It should be noted that emphasis on expanding students' linguistic knowledge would play a positive role in bringing active atmosphere into class teaching. For example, when teachers are lecturing students on five basic sentence patterns (SVC, SV, SVO, SVoO, SVOC), which are dull and difficult to learn, one or two interesting but simple games can be performed alternately, such as English Story Chain. In this game Story Chain, teachers can designate the sentence patter for each student; students need to exert their imagination to complete the story and at the same time they also need to practice each sentence patter given by the teacher flexibly. In this way, students could master the structural connotation about those five basic sentence patterns not only according to the textbooks but also through communicative practice. 


\section{Researches on Grammar Teaching Methods Guided by Educational Psychology}

We now have the above principles as foundations of grammar teaching. In what ways should we as teachers reform our strategies, and develop our methods of systematic teaching? Traditional methods such as induction, deduction and analogy are worth attempting. But teachers should not limit themselves to any one method, and should instead be flexible in their approach. Here we will use the principles of educational psychology to analyze the psychological characteristics of students' grammar learning, which helps us improve our methods.

First, from the perspective of cognitive psychology, we can apply the cognitive approach to the teaching of a second language, i.e. "use common cognitive elements to recognize, analyze, store and create the new language, and encourage learners to analyze the form of the language with self-awareness.”(Huang Hebin, 2002) Cognitive elements are components of the human brain's operations, consisting of seven parts: global features, concepts, images, chunks, meanings, interests, and deductions.

These elements should be used flexibly, and stimulate the students' learning and comprehension of grammar knowledge with multiple methods. We can describe some grammar features with images, giving students vivid impressions to help deepen their understanding. We can organize the patterns of grammar knowledge into formations, strengthening the students' connections between memory, language, and thought. For an example of using images, the author had chosen the following examples in the teaching of articles:

eg: Why should I serve the high and mighty with lowered eyes and on bent knees? Such things can never make my heart rejoice!

A bird is known by its note and a man by his talk.

The students' visual imagination is engaged when they try to understand the two famous Chinses verses above, and their translation exercises are enriched by the literary quality of these sentences. Such exercises in translation and comparative study not only benefit their comprehension of articles, but also stimulate their literary thinking between English and Chinese.

Second, we must understand the students' desire to learn, and reinforce their learning of basic grammar features using cognitive assimilation. According to the educational psychologist Ausubel's knowledge assimilation theory, the learning of the undergraduate phase is a form of meaningful, receptive learning. Generally speaking, a student's preexisting knowledge system has an assimilative effect on new knowledge. Grammar teaching in College English is primarily a further development of grammar points in middle school, and what the students do is to incorporate the new ideas provided by teachers into their preexisting knowledge structure. The interaction of old and new knowledge gives the new grammar points meaning, while reinforcing the old knowledge. For example, in the learning of lexicology, almost every feature is something the students already knew from their middle school. Therefore the teacher can start by listing grammar phenomena, allowing students to utilize their existing knowledge and thinking, to deduct unknown grammar patterns from the phenomena. This allows them to develop habits and abilities to observe and analyze language phenomena by themselves.

Third, we should help students build new grammatical systems. Grammar learning in senior middle school focuses on memorization of language features, with little teaching on grammatical systems, while college students, particularly English majors have an important need to develop the latter. First, the teachers' delivery should clarify the structures, making students grasp both each grammar points on its own and understand the connections within, "to know both how and why". Second, the students' curiosity should be utilized. Humanity's desire of knowledge is generally expressed as curiosity, an interest in unknown things, or known things that have shown new developments. When facing a difference or conflict between their existing grammar knowledge and the new system, the cognitive impact will stimulate the students' desire to learn. The knowledge of students in English major contains basic grammar features but lack systematization. For example, verbs have four basic declensions - tenses, aspects, voices and forms, while students have only scattered memorization of dozens of verb forms, without a systematic understanding of their 
governing patterns. Teachers should take advantages of these conflicts to engage the students, and help them understand the structure of verbs.

Fourth, we should encourage the students' motivation and potential using the constructivist theory. Constructivism is a theory developed by the Swiss psychologist Piaget, which emphasizes that learning is a process through which the learner proactively constructs one's knowledge system and experience, and teaching should not be one-way delivery from teachers to students, rather, students needs to actively engage themselves in learning, and teaching is a constructive process of the students' own experience.(Liu Huashan, Cheng Gang, 2006) Therefore, under the guidance of constructivist theory, grammar teaching should not be centered around one-way delivery as the traditional model, but rather develop an interactive model that encourages the students' active participation.

In the classroom delivery of independent colleges, it is especially important to stir the students' curiosity, and make them more proactive. Before their enrollment at the independent colleges, most students' interests in learning have been suppressed to the lowest point by preparing for the College Entrance Test, while they are often plagued by the problem that their methods are outdated and simplistic, lacking in planning, self-guidance and self-control. Additionally, many students are hesitant towards grammar courses, fearing their reputation of dullness. This means making grammar courses more varied and more interesting a major obstacle for teachers in independent colleges. There are many methods to encourage students to be more active. The author has summarized the following three approaches.

First, we can take advantage of multimedia courseware and equipment, using visuals and audio to make our lessons more varied and more intuitive. For example, when teaching about tenses, we can play movie clips that contain many changes in tenses, allowing students to intuitively understand tense changes as they imitate the dialogue.

Second, we can use classroom games to make the learning more fun and less dull. In independent colleges, especially those specializing in the liberal arts, students are often quite capable of lateral thinking and taking control of actions, which is of great help to making classes livelier. For example, grammar learning requires copious amounts of exercises, such as making choices. We may consider turning the asking and answering process into a questionnaire show, with the teacher playing the role of the host. The questionnaire shows' methods including removal of incorrect options and asking for help from the audience can be used to lower the difficulty of harder problems. This method can add a little competition to engage the students, resulting in a lively class during exercises.

Third, we can exchange places with students, and allow them to experience the joy of success. Increase of motivation lets students to be more confident, and more interested in learning the unknown. For example, when examining a topic with clear structure (such as active and passive voices), we can have students participate in the deduction of grammar features. Students can be divided into groups, and each group can develop their own method for teaching the topic, and show it to other students. During the process, the teacher can give corrections to the students' explanations. Participation not only allows students to understand the topic, but also leaves a deeper impression.

\section{Conclusions}

Nowadays education has gone beyond the traditional model centered around one-way knowledge delivery, putting increasingly more emphasis on the emotional connection between teachers and students. The former Soviet educator and theorist Suhomlinski said, "True education means the subtlest contact of the mind between people, and the school is a world where people's minds touch come into contact." The psychological theory of emotional filtering claims, in the acquisition of language, positive emotional factors, such as the learner's love for the subject will make the learner feel unburdened and happy during learning, making language learning easier. A strong bond between teachers and students is a tremendous force in education. The emotions and encouragements from the teacher can be a subconscious motivation for students. As teachers, we must win the students' dedication with our own sincerity. 
Based on my own grammar classes, our first task is to help students find self-confidence. Most students at independent colleges may have weak English fundamentals, but the learning of grammar is a systematic and long-term process that cannot be done in one leap. During this long journey, the students can improve their knowledge foundation with enough enthusiasm. As students encounter difficulties from time to time, we must help them solve the problems, and build their courage. Once they lose their self-confidence, no amount of passion on the teacher's part will be enough to motivate them.

Second, we should strive to make the classroom more democratic. As teachers we should be magnanimous, always ready for criticism from students, and willing to speak to students on equal terms as another participant in learning. In grammar classes, different students will inevitably approach the same problem with different conceptual models. When delivering the teacher's own model, the teacher must also correct the students' mistakes using appropriate methods; when differences in opinions arise, the teacher should not dismiss the students' opinions offhand. Instead, the teacher should leave everyone time to think, and convince the students with logical examination of the problem, creating an atmosphere of democracy and equality. The non-uniform abilities of students in independent colleges put an even greater need on teachers to treat students equally.

Finally, in addition to delivering knowledge, we should have more emotional communications with students. We need to understand the emotional states of students, and encourage them with our enthusiasm, respect and expectation, so that students can follow the path of their trusted teacher.

In this paper, we have analyzed the current state of English grammar teaching, found the problems in teaching that must be solved, and proposed possible approaches to improving our methods using educational psychology. As teachers, we must have the courage to go beyond the traditional model of teaching, and change our role from the traditional deliverer to a thespian director. Before class, we should make ample preparation of our script, turning the 45-minute class into a participatory stage of language exercise, maximizing the students' proactive learning. We can also realize that educational psychology has a close connection to educational practice, and can provide guidance to the latter. Making use of psychology can help us understand the principles of teaching and learning, develop a mood of learning in class, and achieve better teaching effects.

\section{Acknowledgement}

This paper is sponsored by Key Program of Hubei Education and Science Foundation during the $12^{\text {th }}$ Five-Year Plan Period (GN: 2014A140).

\section{References}

[1]Cui Xuemei, Brief Discussion on College English Grammar Teaching. Modern Science, 2008 (4), p. 241

[2] Huang Hebin, Cognitive English GrammarTeaching. Foreign Languages and Their Teaching, 2002 (2), p. 8

[3] Li Chuan, Research on the Effectiveness of Teaching English Trough Chunks-From the Perspective of Educational Psychology. A School Friend of English, 2009 (09)

[4] Liu Huashan, Cheng Gang, Psychology of Higher Education. Hubei People’s Press, 2006, 1st Ed., pp. $74-77$.

[5] Larsen-Freeman, D. Teaching Language: From grammar to grammaring. Foreign Language Teaching and Research Press, 2005

[6] Sun liwei, The Importance of English Grammar Teaching at College. English on Campus, 2012 (10)

[7] Wang Ansheng, Wang Su, Introduction to Cognitive Psychology. Perking University Press, 2006 